\title{
RELEVANT FACTORS FOR COLLECTIVE ACTION IN THE COMMON-POOL RESOURCES CONTEXT
}

\author{
FATORES RELEVANTES PARA A AÇÃO COLETIVA NO CONTEXTO DOS RECURSOS DE USO \\ COMUM
}

\author{
Andréia Maria Kremer \\ andreiakremer@ufgd.edu.br \\ Universidade Federal do Mato Grosso do Sul - Campo Grande/MS, Brasil \\ http://orcid.org/0000-0002-7162-246X
}

\section{Rafael Todescato Cavalheiro}

rafaeltodescato@hotmail.com

Universidade Federal da Grande Dourados - Dourados/MS, Brasil

http://orcid.org/0000-0002-3468-5357

\section{Olivier François Vilpoux}

o.vilpoux@gmail.com

Universidade Federal do Mato Grosso do Sul - Campo Grande/MS, Brasil

http://orcid.org/0000-0001-8457-2070

\begin{abstract}
This study sought to identify the relevant factors for collective action in the context of the use of common goods and what factors are influential in the cooperation between individuals. For this, an integrative analysis of 267 articles was carried out, published in the Scopus, Science Direct and Web of Science databases. The results show little progress in the inclusion of new analysis factors and the presented factors do not have linear effects on all collective actions, and advances are necessary for a more complete theory.
\end{abstract}

Keywords: Common-pool resources. Collective action. Cooperation. Cooperative.

\section{Resumo}

Este estudo buscou identificar os fatores relevantes para a ação coletiva no contexto do uso dos bens comuns e quais fatores são influenciadores da cooperação entre indivíduos. Para tanto, foi realizada uma análise integrativa de 267 artigos, publicados nas bases de dados Scopus, Science Direct e Web of Science. Os resultados demonstram poucos avanços na inclusão de novos fatores de análise e os fatores apresentados não possuem efeitos lineares sobre todas as ações coletivas, sendo necessários avanços para uma teoria mais completa.

Palavras-chave: Recursos de uso comum. Ação coletiva. Cooperação. Cooperativo. 


\section{Introduction}

Over-exploitation and possible scarcity of natural resources have been discussed by a number of authors from various fields of knowledge over time. In the economic context such discussions began with the studies of economists H. Scott Gordon (1954) and Antony Scott (1955), who addressed the overexploitation of fishery resources. In 1968, Garret Hardin proposed the concept of tragedy of the commons, by associating it with the fact that individuals are driven to limitlessly exploit resources in a world of limited resources. This search for self-interest to the detriment of general interests can be considered the great tragedy of the commons (HARDIN, 1968).

To minimize the impacts of this self-interested attitude, Gordon (1954) suggested the need to create mechanisms to protect and regulate the use of common-pool resources. Theories related to this type of resource have traditionally presented as mechanisms private control through the clear definition of property rights (SINN, 1984; SMITH, 1981) or public coordination (CARRUTHERS; STONER, 1981). However, property rights are possible in static goods, but in non-static goods such as water or fisheries, this solution is more difficult (OSTROM, 1990). Ostrom (2000b) understands that the collective action of groups can be a determining factor in solving the tragedy of the commons.

Olson (1965) in proposing the Theory of Collective Action mentioned the possibility of organizing groups into collective actions, but was limited to very small groups, which he defined as privileged, or intermediate, where the activities of members are easily monitored by others, which limits the possibilities of free riders. For the author, in the larger or latent groups, collective action necessarily involves the existence of mechanisms of coercion or external incentives.

Contrary to Olson's propositions, Ostrom $(1990,1998)$ presents several examples that demonstrate the possibility of individuals self-organizing to achieve collective benefits. Self-organized groups can do what governments and markets cannot do, given that their members have crucial information about the behaviors, capacities and needs of other members (BOWLES; GINTIS, 2002). In addition, other factors influence the cooperative behavior of individuals to perform collective actions, and not exclusively the self-interest (OSTROM, 2000a).

In this context, norms such as reliability, trust and a sense of justice lead individuals to act in some situations in a way directly contrary to those provided by the rational egoist theory (OSTROM, 2005). This view being a critical approach to the assumption of economic utility, based on the selfish interest of the individual, presented by economic theories.

In this sense, this study aims to identify the relevant factors for collective action in the context of the use of commons and which factors influence the cooperation between individuals. The main contribution of this study is the identification of the main studies on collective actions and commons, identification of the factors used in studies of cooperative behavior, as well as the gaps in the explanation of cooperation between individuals.

\section{Theoretical Framework}

The Collective Action Theory was developed mainly through the assumptions of two authors, Mancur Olson, with the publication of the book Logic of Collective Action, in 1965, and Elinor Ostrom, with the book Governing the Commons - The Evolution of Institutions for Collective Action, in 1990.

For Olson (1965), common-pool resources are those from which an individual cannot be excluded from obtaining their benefits and once it is produced, that individual has little incentive to voluntarily contribute to the provision of the good. For the author, there are different behaviors between individuals in the provision of good, with some people acting opportunistically in the activities of others. This difference is explained by different value assignments by each individual to the resource. For Olson 
(1965), the only groups where collective action is guaranteed are privileged groups, which are limited to small groups where one or a few individuals have sufficient gains from the collective good to assume the full costs of obtaining this good alone.

In the theory developed by Olson, the behavior of agents is explained exclusively by the economic utility of the good. Ostrom, in his 1990 work and subsequent studies, presents a critique of the exclusive use of economic utilitarianism in Collective Action Theory and presents a number of other factors that may influence the cooperative behavior of individuals. The author's main criticism refers to the fact that all individuals are considered equal, named by her as selfish rationals, focused on their self-interest. In contrast to this assumption, some authors claim that the world contains various types of individuals, some more willing than others to initiate reciprocity and achieve the benefits of collective action (BOWLES; GINTIS, 2002; OSTROM, 2000b).

Ostrom (1998) argues that human nature is a complex mixture of the pursuit of self-interest combined with the ability to acquire internal norms of behavior and to follow rules when understood and perceived as legitimate. Researchers of evolutionary theories have argued that humans are born with the ability to learn norms of reciprocity and general social norms, which increase the returns of collective action (OSTROM, 1998, 2000a).

Social norms are shared understandings about actions that are mandatory, permitted, or prohibited (CRAWFORD; OSTROM, 1995; OSTROM, 2005). These norms are initially learned in family relationships and, therefore, may differ from one culture to another (BOWLES; GINTIS, 2002; OSTROM, 2000b). Over time and in situations they are constructed and deconstructed through human interaction (CRAWFORD; OSTROM, 1995). Communication is presented as an important factor in the elaboration and legitimization of norms and rules in a group (OSTROM, 1994, 1998, 2000a; OSTROM; GARDNER; WALKER, 1994) and face-to-face communication is a factor that directly influences trust and, consequently, collective action (WENNINGKAMP; SCHMIDT, 2016).

The trust aspect, through interaction between individuals, is a very important factor in solving collective action problems, as they are determinant in relations and levels of cooperation (OSTROM, 2010b; OSTROM, 1998). These relationships are tied to social capital, which usually refers to trust, concern for group members, willingness to live by community norms, and punishing those who do not (BOWLES; GINTIS, 2002; OSTROM; AHN, 2006). Reciprocity norms, networks and forms of civic engagement, and formal and informal institutions are presented as generating factors of social capital. Ostrom and Ahn (2006) mention that the various forms of social capital are responsible for developing trust, which facilitates collective action.

Despite the importance of the rules created and legitimized by the group, for them to be effective in collective action it is necessary to have the monitoring of actions and the punishment of those who do not behave correctly (BOWLES; GINTIS, 1998; OSTROM, 1992). Monitoring can be performed by various mechanisms, with external monitors unrelated to the group, monitors contracted by the group or done by the users themselves (OSTROM, 1990). Monitoring should be accompanied by sanctions on those who do not comply with group rules through formal or informal mechanisms developed by the group itself (OSTROM, 1990). It is important to mention that monitoring and punishment are essential elements for long-term collective action, since if the possibility of being punished is low, instability may grow over time, but if the risk of punishment is high, individuals can expect others to act according to the rules (BOWLES; GINTIS, 2002; OSTROM, 2005). For Ostrom (2010) the sanctions should be gradual, starting small and rising in case of recurrence.

In addition to these aspects, others have been widely discussed in the collective action theory, such as group size and heterogeneity. The size of the group was first discussed by Olson (1965) in relating the success of collective action to very small groups and the objectives of collective action, differentiating between inclusive and exclusive groups. Generally, authors argue that in small groups, members tend to 
have frequent relationships and therefore have access to more information about each other's actions and preferences, and have a strong incentive to consider the long-term consequences of their choices (BALAND; PLATTEAU, 1996, 1999). Smaller groups have advantages over larger ones because they are more homogeneous and homogeneity is considered an important factor for the success of collective action (BALAND; PLATTEAU, 1996; OSTROM, 2000a; VEDELD, 2000).

The heterogeneity factor of groups is associated with the success of collective action and is related to cultural aspects, the differences in the nature of interests, that individuals may have in a particular collective action, and the variation in the availability of resource endowments (BALAND; PLATTEAU, 1996; BARDHAN; DAYTON-JOHNSON, 2002; GAUTAM, 2007; OSTROM, 1990, 2000a, 2005; VARUGHESE; OSTROM, 2001; VEDELD, 2000).

In addition to the aspects addressed, Ostrom (1990, 2000b) identified eight recurring principles in successful collective actions related to common-pool resources: 1) Clear boundaries; 2) Equivalence between costs and benefits; 3) Collective choice agreements, with the participation of all; 4) Efficient monitoring; 5) Gradual sanctions; 6) Simple and fast conflict resolution mechanisms; 7) Legitimacy of internal norms vis-à-vis external forces; and 8) Multiple layers of nested enterprises in larger groups. The literature addresses the principles cited by Ostrom individually or together.

In this sense, we seek to identify, through the proposed methodology, how these factors have been applied in scientific studies and the presence or absence of new factors of analysis in the context of collective action and the use of common resources.

\section{Methodology}

In order to meet the objective of this study, the integrative literature review methodology was used, an approach that allows the inclusion of different methodologies and has the potential to present the state of science, varied perspectives on a phenomenon and contribute to the development of theory (WHITTEMORE; KNAFL, 2005).

Primary data were collected from the Scopus, Web of Science and Science Direct databases, from October 5 to 11, 2017. Data collection was based on the keywords "collective action" AND "commompool resources"; "Cooperation" AND "commom-pool resources"; "Cooperative" AND "commompool resources". In the Web of Science database was searched by the terms in the topic, in Scopus and Science Direct the search was performed in Article title, Abstract and Keywords. In all databases were used as filters the search for articles and reviews, in Portuguese, English and Spanish, without limiting the period. The results were imported into StArt software, version 3.3, for the purpose of organizing, classifying and analyzing the studies. Flowchart 1 presents the steps performed and the number of studies selected in each phase. 
Flowchart 1- Steps and quantitative results of data extraction

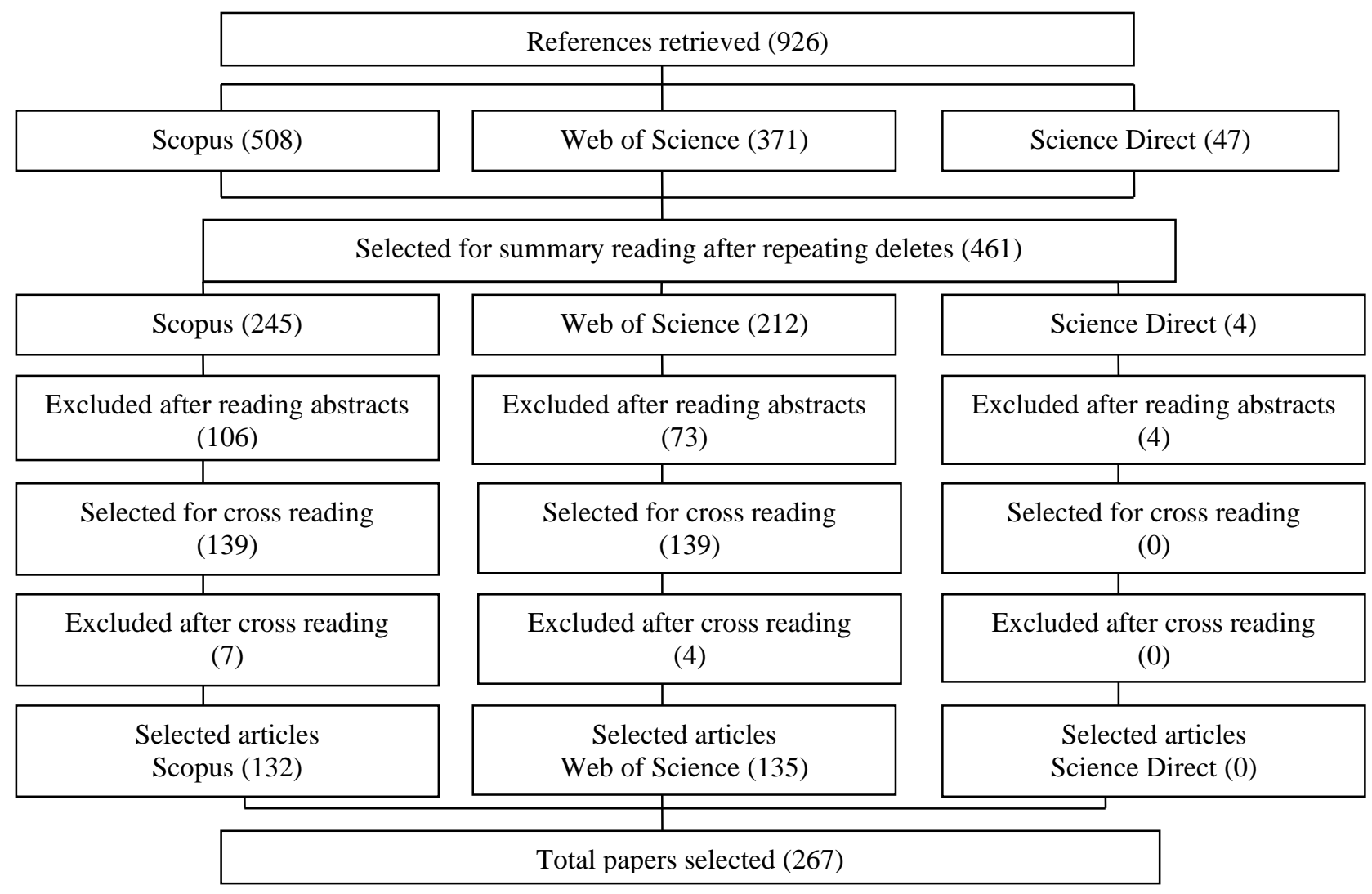

As shown in Flowchart 1, the repeated articles were initially eliminated. Then, the selected articles underwent a first evaluation by reading the titles and abstracts. In this phase, articles that did not address the proposed themes, articles in languages other than those specified in the protocol, and materials that did not fit into journal articles, such as book chapters and conference articles, were eliminated. After selection by titles and abstracts, a cross-sectional reading of the selected articles was performed to make a new selection, resulting in 267 articles, which form the database for this study. The analysis of the selected studies is presented in the following section.

For the analysis of the network formed by the authors of the study, a square matrix partner was elaborated (HANNEMAN, 2001), and based on the matrix, the publications relations network was generated and the authors' degree of centrality was calculated using the software ORA v.2.3.6 (Organizational Risk Analyzer), specific to network analysis.

\section{Results and Discussions}

The results present the findings derived from the search for articles on the subject under study and the relevant factors addressed in the literature.

\section{Collective Action Literature and Common Problems}

For a long time scientific studies have addressed the question of the exploitation of natural resources by human activity. Clearly, concern about the scarcity of some natural resources and the pollution of many others has influenced a significant increase in studies seeking alternatives to solve common-pool resource dilemmas. 
Although not limiting the time period in the search and use, in addition to the term collective action, the terms cooperation and cooperative, were only obtained data from the year 1992, being the 2 articles of the year authored by Elinor Ostrom, in which the author presents the importance of community, cooperation, and communication in solving common resource dilemmas (OSTROM, 1992; OSTROM; WALKER; GARDNER, 1992). From the discussions proposed by Ostrom, the number of studies addressing collective action in common use resources increased significantly from the year 2010, possibly justified by the increased focus on problems of exploitation of natural resources and the role of individual as a solution to the tragedy of the commons.

Among the studies analyzed, 20 were published until 1999, 66 until 2009 and 181 after 2010. The year 2016 had the largest number of publications (41), demonstrating the increased approach over the last few years. This increase in research on the subject likely be justified by the increased focus on problems of exploitation of natural resources and the role of the individual as a solution to the tragedy of the commons. In the late 1990s, various conferences and actions were held with a focus on preserving the environment as a result of discussions initiated in Stockholm. These actions include the United Nations Conference on the Environment and Development (UNED), known as Rio-92 in 1992, International Labor Organization (ILO) Convention 174 in 1993, the International Conference on Population and Development (ICPD) in 1994, bringing together 179 countries, and the Third Conference of the Parties (COP-3), culminating in the Kyoto Protocol in 1997. Increased discussions and actions between various countries over the years have increased attention and directed the focus of many researchers to the preservation of common use resources.

Due to the importance of the common-pool resource dilemma over the last few years, international journals are moving towards greater interest in these issues. To give greater visibility to commons problems, the International Association for the Study of the Commons, in partnership with the University of Utrecht, has created the International Journal of the Commons to publish studies with advances in solving common-use resource dilemmas. Due to its focus, this is the journal that has the largest number of published articles, among those selected, with 25 articles, followed by Ecological Economics, with 20 articles, and Ecology and Society, with 16 articles.

Most journals, with the largest number of publications, are found to be journals related to ecology and environmental management, demonstrating a much greater application of the collective action theory to environmental commons, following the application initially used by Ostrom. However, the discussion of the collective action theory began in non-exclusively environmental approaches, and was applied to various non-environmental objects, such as residential condominiums, cooperatives, management of organizations and international relations. Despite the possibility of application in various fields and its multidisciplinary nature, the publication of the subject is still incipient in journals in other areas, with only a few publications in recent years. This situation demonstrates an opportunity for the development and application of the theme to objects related to organizational management, cooperative management and public administration.

In addition to the creation of specific journals, some institutions have set up groups or study centers that focus on the commons, which make a relevant contribution to the subject, such as the Center for the Study of Institutional Diversity at Arizona State University. This initiative by researchers and institutions is reflected in publications on the topic, as the authors with the most publications, Elinor Ostrom and Marco A. Janssen, participated in the center throughout their career. Ostrom pioneered the analysis of collective action as a solution to the tragedy of the commons, and the author also directed the Research Center for a while. Janssen participates in the Center and serves as a professor at Arizona State University (USA). It can be seen that eight of the twelve authors who published the most, are from the United States, predominantly from Indiana University and Arizona State University.

Research centers have historically been perceived as sources of new ideas and can help guide research and education activities to the needs of society by bringing experiences with knowledge transmission and 
introducing innovation-oriented approaches in all activities. In this sense, it is justifiable that many of the researches on the subject come from researchers linked to this research center.

Ostrom also features prominently among the 10 most cited articles in the Scopus database. The researcher is among the authors of 4 of the top 10 in the ranking, and the most cited article, published in the journal Science, was cited 1054 times by scholars in the field. The other articles have between 198 (2nd ranking) and 85 citations (10th ranking). The articles with the largest number of citations are mostly theoretical studies, and only those from Cardenas (2003) and Agrawal and Goyal (2001) have an empirical approach. Therefore, the results suggest that such studies represent the framework for the analysis of collective action in the context of common use resources and this is justified by their high impact in this area of study.

Besides the number of articles published, it is possible to see the importance of study centers on the subject in the analysis of the author network. Figure 1 shows the network of authors of the analyzed studies.

Figure 1 - Network of Authors Addressing Collective Action on Commonly Used Resources

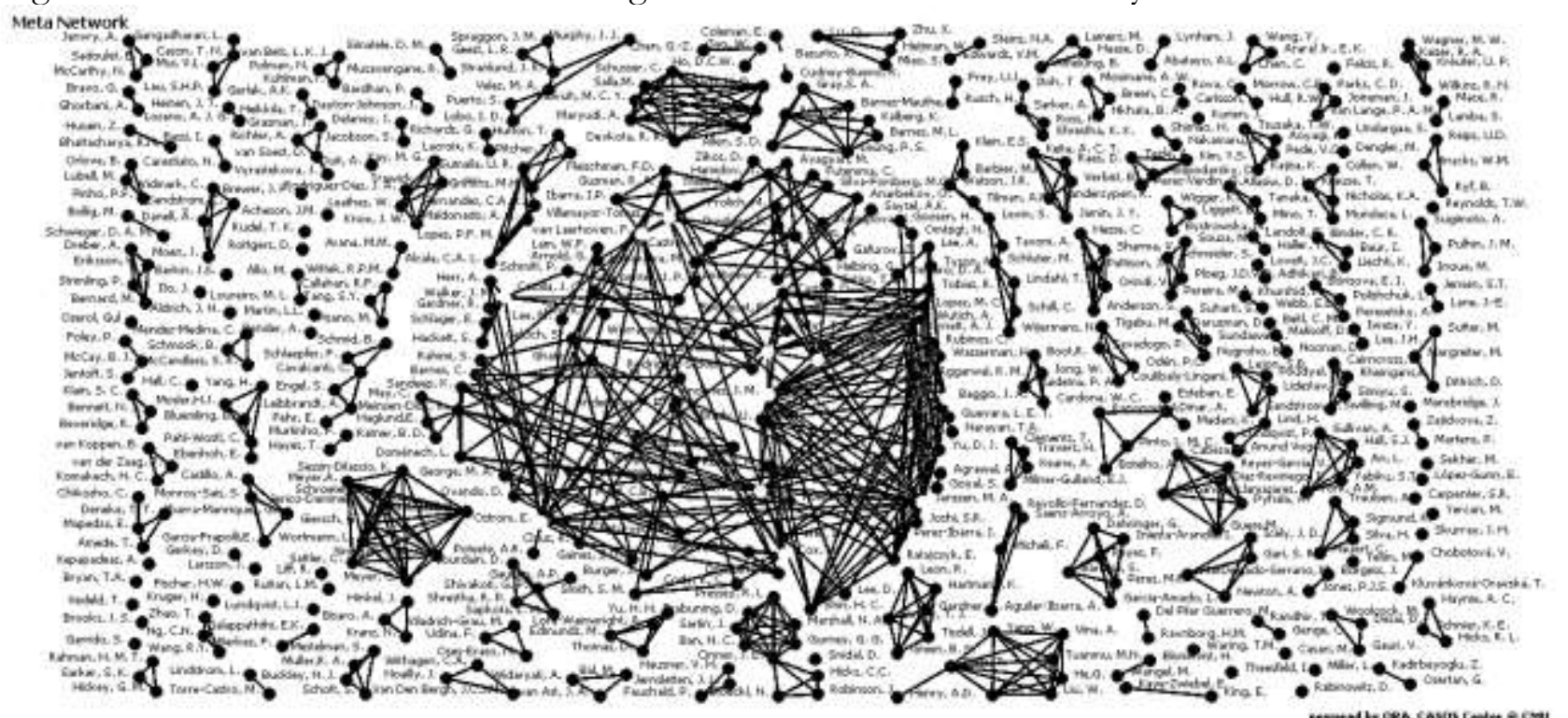

The articles on the subject under study were written by 552 authors. Of these, Figure 1 shows that many are related only to their coauthors, that is, they do not have a wide network of publications, and many have only one identified article on the subject. However, it can be seen that a group in the center stands out for its multiple authoring relationships and, therefore, a dense network of publications. Among them, there is the presence of the authors with the largest number of publications, highlighted in yellow. Although Elinor Ostrom is the author with the largest number of publications, Marco A. Janssen stands out in terms of relationships, mainly explained by the fact that Ostrom has several publications as sole author, while Janssen has a predominance of publications with several co-authors. The author's prominence in the network is represented by the number of relationships he has, 33, followed by Anderies, J. M. with 23 and Rollins, N. D. with 17.

The number of contacts you have on the network, along with the number of publications with each author, impact on the degree of centrality of the author in the network formed, measured by the number of ties you have (WASSERMAN; FAUST, 1994). According to Hanneman (2001), if an actor receives many links directed to him, he is considered to have prestige in the network, that is, many other actors seek to share information with him, which may indicate its importance. In this sense, the author with the greatest relevance in the network of publications on the subject is Janssen, with a degree of centrality of 0.018. The results obtained in the analysis of the network demonstrate the importance of the Center for 
the Study of Institutional Diversity, given the outstanding performance of its members in the joint publication and the formation of an important research network on the subject.

Research networks are extremely important in knowledge generation, as they enable shared learning, new research opportunities, establishment of new research projects, and joint solicitation of funds (PULJAK; VARI, 2014). In addition, collaborations increase citations of research manuscripts, especially if there is an international team of authors involved, such as the network presented. In this sense, the formation of a research network allows the researched subjects to have a broader approach and greater dissemination in the scientific field. Moreover, having a strong publication network on the subject favors the development of the theory, given the specialization of the members of the network.

Through the analysis of the selected articles, it appears that there is a pattern in the analyzed variables, limiting itself to empirical applications in various environments, with the purpose of confirming or not the factors discussed above.

\section{Relevant Factors for Collective Action and Common Problems}

Regarding the content of the selected articles, initially were identified the types of common goods that served as the object of analysis in the studies, which are resources of common use in general ( 77 studies). This is the case with many studies that use laboratory experiments with university students, for example. Among the studies that analyze collective actions and cooperation in specific common-pool resources, there is a predominance in the analysis of fishery (37), water (27), marine (10) and forest (23), irrigation systems (33), community forests (11), grasslands (10), traditional communities (3), national parks (3), transnational relations (3) and multifamily buildings (7), such as condominiums. Regardless of the type of asset used, there is a predominance of the factors analyzed in each study, as shown in Table 1.

Table 1 - Factors analyzed in selected studies

\begin{tabular}{lclc}
\hline Factors analyzed & Quantity & Factors analyzed & Quantity \\
\hline Norms & 41 & Leadership & 9 \\
Heterogeneity & 38 & Cultural aspects & 9 \\
Ostrom Design Principles & 36 & Reciprocity & 8 \\
Communication & 20 & Self management & 8 \\
Punishments & 20 & Property rights & 7 \\
Social Capital & 19 & Resource attributes & 7 \\
Group Size & 19 & Multilevel governance & 7 \\
Trust & 18 & Institutions & 7 \\
Participation & 12 & Networks & 6 \\
Rules & 11 & State role & 6 \\
Monitoring & 10 & Decision-making & 6 \\
Incentives & 9 & Previous experiences & 5 \\
\hline
\end{tabular}

As shown in Table 1, one of the main factors researched in the identified studies are the norms. Norms are analyzed as solutions to collective action problems, whether established by external agencies or internally created. Some studies argue the importance of applying external norms regulating the behavior of agents, and that when there are external norms with penalties, the internal norms of the group are not efficient (TRAVERS et al., 2011). According to these authors, internal norms are not sufficient to restrict the opportunistic behavior of free-riders (opportunists who do not cooperate but enjoy the benefits of collective action), and in this case, the imposition of external norms is indispensable for free riders successful cooperation. However, several authors argue that groups are able to create norms internally, that they have legitimacy vis-à-vis the group and are efficient in establishing criteria that are allowed or prohibited, regardless of the existence of broader external norms (DECARO; JANSSEN; LEE, 2015; OSTROM; AHN, 2006). 
The authors who defend the elaboration of internal norms in a group, affirm that they make possible the cooperation between the individuals, since the norms are created through agreements considered fair and legitimate by the participants. Deneke, Mapedza and Amede (2011) analyze the importance of participation in the elaboration of cooperation rules in the preservation of water resources, and defend the legitimacy of the rules before the group and before external regulatory bodies. In this sense, the factors: communication, participation, rules, punishment and monitoring, analyzed in various studies, are directly related to the norms, since through communication and participation the internal rules are determined and are guaranteed through monitoring and punishment.

Selected research shows that the effectiveness of internal and external standards is combined with the possibility of monitoring and sanctions for those who do not comply with the rules. As mentioned earlier, monitoring has been advocated by several authors as essential for successful cooperation. However, there is no consensus on the sources of monitoring and their role in collective action. Baland and Platteau (1996) argue for the need for external monitoring systems to compensate for various deficiencies in decentralized punishment mechanisms. Ostrom (1990) argues that external agencies do not have enough information for effective monitoring and would need to hire monitors to perform the work. Ensuring that these monitors would actually do the job is considered a challenge for the author. Vogel, Lind and Lundqvist (2016) agree with Ostrom and claim that the precarious situation in the Swedish cooperative housing sector is an environment in which external authorities impose rules but can only perform weak monitoring and sanctions. Ostrom (1994) argues for internal monitoring by claiming that the self-interest of those who negotiated the agreement will lead them to monitor each other.

Van Laerhoven and Andersson (2013), in a study conducted in forest governance communities, identified that groups with internal monitoring systems have higher rates of conflict between cooperating and noncooperating individuals. However, regardless of conflicts, the authors demonstrate that in these groups the success of collective action is greater than in those who do not monitor. Agrawal and Goyal (2001) analyze the relationship between group size and the type of monitoring adopted and argue that there is no success pattern for cooperation in relating the two characteristics. That is, despite the importance that monitoring plays in collective action, there is no consensus on the type of monitoring to be used and its role in the cooperation of individuals. However, there is a consensus that in the presence of monitoring there must be punishments for those who do not cooperate.

Sanctions are indispensable tools for effective monitoring, but to be effective, they need to be considered fair by participants and costly, so that non-cooperators consider the costs of breaking the rules. Geest, Stranlund and Spraggon (2017) analyzed the impact of the sanction on the number of free-riders and found that in cases where sanctions were low, free-riders continued to exist. In addition, the authors found that in cases where rule breaks were small, many co-workers would stop punishing and this would lead to further future breaks.

Cox, Arnold and Villamayor (2010) mention that some authors question the role of sanctions, claiming that this principle ignores the underlying social relations. Authors have considered these social relationships by associating them with cultural heterogeneity, power relations, or resource heterogeneity. Özerol (2013) studied irrigated areas in Turkey and identified that the group analyzed had effective monitoring but lacked effective sanctions due to the heterogeneous community structure regarding resources and power. In this sense, the sanctions were not considered equally fair to the participants. Bardhan and Dayton-Johnson (2002) argue that the effectiveness of social sanctions also weakens by traversing ethnic reference groups in which cultural norms can define different values of justice. In this case, the positive effects of norms, monitoring and sanctions are associated with the analysis of other important factors for collective action, such as group size and heterogeneity.

Group heterogeneity is the second most analyzed aspect in the studies, considering the three types of heterogeneity defended by Ostrom (1990; 2000a; 2005), Baland and Platteau (1996), Bardhan and Dayton-Johnson (2002), Gautam (2007), Varughese and Ostrom (2001) and Vedeld (2000). Examples 
include studies that identified the negative aspects of heterogeneity of knowledge levels, age level, mode of possession and lifetime (GAO; CHEN, 2016), asymmetries in funding, power and culture (MILLER, 2016), capacities and interests (OSTROM, 1994; VEDELD, 2000), cultural and social (RUTTAN, 2006) and income inequality (AGGARWAL; NARAYAN, 2004). Regarding cultural heterogeneity, Baland and Platteau (1996) mention that it can have a negative impact on group cooperation, since it can lead to different interpretations of rules, social conventions and norms supporting cooperation. Cultural heterogeneity can make it difficult to build consensus and enforce rules because of a lack of common understanding, and consequently hinder cooperation (GAUTAM, 2007; MILLER, 2016; RUTTAN, 2006; VARUGHESE; OSTROM, 2001).

The second factor of heterogeneity considered is the difference of interests. Vedeld (2000) states that homogeneity in economic interests is an absolute prerequisite for collective action in a social group. When members of a group have different interests in managing a resource, defining a common goal is a challenge (BALAND; PLATTEAU, 1996; OSTROM, 2000b; VARUGHESE; OSTROM, 2001). Some authors have associated the heterogeneity of interests with gender issues, mentioning that different interests between men and women may lead to different perceptions of cost and benefits (VARUGHESE; OSTROM, 2001, age (GAO, 2015; GAO; CHEN, 2016; TABERNERO et al., 2015), as well as the different perceptions about the facts (MANGO et al., 2017; SOETANTO; MULLINS; ACHOUR, 2017; WEISS; SCZESNY; FREUND, 2016).

The third source of heterogeneity is the possibility of different amounts of resources. According to Baland and Platteau (1996), while the first two causes of heterogeneity are a strong impediment to collective action, the same cannot be said of the third cause. As mentioned earlier, the difference in resources may be a limiting factor for the imposition of sanctions due to protectionist behaviors. Varughese and Ostrom (2001) state that, despite recurring arguments that homogeneous groups are more successful in collective action, heterogeneity does not have a linear effect on the likelihood of collective action and a small effect on the sustainability of these actions. As mentioned by Poteete, Ostrom and Janssen (2011), some studies have identified that heterogeneity does not have the same effects in all cases, i.e. it needs to be analyzed in conjunction with other factors (AGGARWAL; NARAYAN, 2004; RUTTAN, 2006). In the same way, Wenningkamp and Schmidt (2016), from an analysis of several studies on collective action in agribusiness, mention that heterogeneity cannot be predefined as a positive or negative factor for the formation or maintenance of groups, because it depends on other variables and situations analyzed. Disagreements also happen with the role of group size. In general, the literature argues that smaller groups have advantages in the possibilities of collective action, however, it had different effects among the analyzed studies (AGRAWAL; GOYAL, 2001; GAUTAM, 2007; SIMIYU et al., 2017).

Several studies of empirical analysis in groups have analyzed the presence or absence of the aspects identified by Ostrom (1990) and present in the successful collective actions of common-pool resources. In general, the results show that these principles do not have a constancy in the collective action groups, that is, each of the principles has different applications according to the type of group studied (BAGGIO et al., 2016; CARDONA et al. , 2014; COX; ARNOLD; VILLAMAYOR, 2010; GARI et al., 2017; VOGEL; LIND; LUNDQVIST, 2016; WILSON; OSTROM; COX, 2013).

The factors group size, heterogeneity and norms are related to the factors social capital, trust and reciprocity. The literature argues that smaller, homogeneous groups with internal norms have greater trust and reciprocity among participants, thus obtaining greater social capital in the group (OSTROM, 1994; OSTROM; AHN, 2006).

\section{Final Considerations}

This study aimed to identify how the collective action theory has been applied to the common use resource dilemma, the profile of publications and the factors analyzed as influencing cooperation between 
individuals. In general, numerous publications in the international databases and a quantitative evolution over the last years have been identified. Some authors stand out for the large number of publications on the subject, however it is clear that the subject is being the subject of interest of studies, and more and more people, since in the analysis of selected articles there is a significant number of different authors.

The highlight is mainly related to the creation of a research center on the subject, enabling the creation of a dense network of information and knowledge sharing. Another factor that demonstrates the relevance of the subject in recent years is the creation of a specific journal on the topic. Another factor that demonstrates the relevance of the topic in recent years is the creation of a specific journal on the subject, bringing together different approaches, from multidisciplinary fields and different research objects.

Analysis of common-pool resources has long been associated with the exploitation of natural resources. However, over time it has begun to be applied to various other types of resources that are used by communities generally and have the characteristic of not allowing the exclusion of beneficiaries such as health services, multi-family condominiums and security relationships between countries. In addition, the Collective Action Theory has been applied to aspects other than common resource, albeit incipiently, demonstrating an important opportunity for academic research.

In general, the Theory of Collective Action, proposed by Elinor Ostrom, is not focused on commonpool resources, but on the most diverse forms of collective action between individuals, through selforganization. As argued by Bryan (2004), collective action initiatives are very relevant because sharing among group members allows for a sense of shared ownership of larger and complex problems.

However, despite advances in the number of studies, author networks, and resource types, the factors for analyzing cooperative behavior are limited to the factors initially advocated by Elinor Ostrom. It was found that the studies are based on the evidence of the presence or absence of characteristics of individuals, groups and goods, which have a positive or negative impact on collective actions and were defended by Ostrom. The studies presented different results according to the context in which they were applied, demonstrating that the defended characteristics do not have a linear effect in explaining collective action.

The identification of the main factors of analysis and their different implications, in multiple situations and objects, lead to a reflection on the need to deepen the collective action theory. In this sense, there are challenges to be overcome in explaining the cooperative behavior of individuals. Among these challenges, the analysis of the opinions, perceptions and cognitive aspects of individuals can be crucial for understanding the reasons that explain a more collaborative behavior of some individuals in relation to others. Another aspect that should be taken into consideration is the type of asset and the type of group adopted in each situation, as the presence of use subtractability or the possibility of exclusion from the group may influence the aspects considered relevant to each situation.

The use of multiple methods, which has already been used by various authors, can be useful for analyzing these different aspects, as well as to assist in solving the challenges related to cooperation. The discovery of a wide variety of methods provides the basis for developing more complete theories to complement the factors advocated by collective action researchers.

The main contributions of this study are the presentation of the evolution of research on the subject, the indication of the main researchers, as well as the importance of research centers. In addition, this study identified the factors addressed in the literature to explain collective actions and identified gaps that need to be overcome in order to create a more complete theory of human behavior. This is a relevant agenda for future research. 
It is worth mentioning that this study presented as limitations the fact that most of the abstracts did not present sufficient information about the methods used, the objects of analysis and the factors analyzed. Thus, it is necessary to reflect on the inclusion of relevant information in the abstracts and keywords of the articles, for the correct identification of relevant searches in the databases.

\section{References}

AGGARWAL, R. M.; NARAYAN, T. A. Does inequality lead to greater efficiency in the use of local commons? The role of strategic investments in capacity. Journal of Environmental Economics and Management, v. 47, n. 1, p. 163-182, 2004.

AGRAWAL, A.; GOYAL, S. Group Size and Collective Action: Third-party Monitoring in Commonpool Resources. Comparative Political Studies, v. 34, n. 1, p. 63-93, 2001.

BAGGIO, J. A. et al. Explaining success and failure in the commons: The configural nature of Ostrom's institutional design principles. International Journal of the Commons, v. 10, n. 2, p. 417-439, 2016.

BALAND, J. M.; PLATTEAU, J. P. Halting Degradation of Natural Resources. Is There a Role for Rural Communities? Oxford: Oxford University Press, 1996.

BALAND, J. M.; PLATTEAU, J. P. The ambiguous impact of inequality on local resource management. World Development, v. 27, n. 5, p. 773-788, 1999.

BARDHAN, P.; DAYTON-JOHNSON, J. Unequal Irrigators: Heterogeneity and Commons Management in Large-Scale Multivariate Research. In: OSTROM, E. et al. (Eds.). . The Drama of the Commons. Washington, DC: National Academy Press, 2002. p. 87-112.

BOWLES, S.; GINTIS, H. The Moral Economy of Communities: Structured Populations and the Evolution of Pro-Social Norms. Evolution and Human Behavior, v. 19, p. 3-25, 1998.

BOWLES, S.; GINTIS, H. Social capital and community governance. The Economic Journal, v. 112, p. F419--F436, 2002.

BRYAN, T. A. Tragedy Averted: The Promise of Collaboration. Society \& Natural Resources, v. 17, n. 10, p. $881-896,2004$.

CARDENAS, J. C. Real wealth and experimental cooperation: Experiments in the field lab. Journal of Development Economics, v. 70, n. 2, p. 263-289, 2003.

CARDONA, W. C. et al. Diverse local regulatory responses to a new forestry regime in forest communities in the Bolivian Amazon. Land Use Policy, v. 39, p. 224-232, 2014.

CARRUTHERS, I.; STONER, R. Economic Aspects and Policy Issues in Groundwater Development. World Bank staff working paper. [s.l: s.n.].

COX, M.; ARNOLD, G.; VILLAMAYOR, S. A Review of Design Principles for Community-based Natural Resource Management. Ecology and Society, v. 15, n. 4, p. 38, 2010.

CRAWFORD, S. E. S.; OSTROM, E. A Grammar of Institutions. The American Political Science Review, v. 89, n. 3, p. 582-600, 1995.

DECARO, D. A.; JANSSEN, M. A.; LEE, A. Synergistic effects of voting and enforcement on internalized motivation to cooperate in a resource dilemma. Judgment and Decision Making, v. 10, n. 6, p. 511-537, 2015. 
DENEKE, T. T.; MAPEDZA, E.; AMEDE, T. Institutional implications of governance of local common pool resources on livestock water productivity in Ethiopia. Experimental Agriculture, v. 47, n. S1, p. 99-111, 2011.

GAO, W. Collective actions for the management of multi-owned residential building: A case of Hong Kong. Habitat International, v. 49, p. 316-324, 2015.

GAO, W.; CHEN, G. Z. Does owner heterogeneity matter in the management of multi-owned housing? Habitat International, v. 53, p. 106-114, 2016.

GARI, S. R. et al. An analysis of the global applicability of Ostrom's design principles to diagnose the functionality of common-pool resource institutions. Sustainability (Switzerland), v. 9, n. 7, 2017.

GAUTAM, A. P. Group size, heterogeneity and collective action outcomes: evidence from community forestry in Nepal. International Journal of Sustainable Development \& World Ecology, v. 14, n. 6, p. 574-583, 2007.

GEEST, L. R.; STRANLUND, J. K.; SPRAGGON, J. M. Deterring poaching of a common pool resource. Journal of Economic Behavior \& Organization, v. 141, p. 254-276, 2017.

GORDON, H. S. The Economic Theory of a Common-Property Resource : The Fishery. Journal of Political Economy, v. 62, n. 2, p. 124-142, 1954.

HANNEMAN, R. A. Introduction to Social Network Methods. Riverside: University of California, 2001.

HARDIN, G. The tragedy of the commons. Science, v. 162, n. June, p. 1243-1248, 1968.

MANGO, N. et al. Awareness and adoption of land, soil and water conservation practices in the Chinyanja Triangle, Southern Africa. International Soil and Water Conservation Research, v. 5, n. 2, p. 122 129, 2017.

MILLER, L. Geographies of Governance Across La Amistad International Park. Journal of Sustainable Forestry, v. 35, n. 1, p. 16-36, 2016.

OLSON, M. The Logic of Collective Action: Public Goods and the Theory of Groups. Cambridge: Harvard University Press, 1965.

OSTROM, E. Governing the Commons: The evolution of Institutions for Collective Action. Cambridge: Cambridge University Press, 1990.

OSTROM, E. Community and the endogenous solution of commons problems. Journal of Theoretical Politics, v. 4, n. 3, p. 343-351, 1992.

OSTROM, E. Constituting Social Capital and Collective Action. Journal of Theoretical Politics, v. 6, n. 4, p. 527-562, 1994.

OSTROM, E. A Behavior Approach to the rational choice theory of collective action. American Political Science Association, v. 92, n. 1, p. 1-22, 1998.

OSTROM, E. Reformulating the commons. Swiss Political Science Review, v. 6, n. 1, p. 29-52, 2000 a.

OSTROM, E. Collective Action and the Evolution of Social Norms. The Journal of Economic Perspectives, v. 14, n. 3, p. 137-158, 2000b.

OSTROM, E. Understanding Institutional Diversity. Princeton-NJ: Princeton University Press, 2005. 
OSTROM, E. Beyond Markets and States : Polycentric Governance of Complex Economic Systems. American Economic Review, v. 100, n. 3, p. 641-672, 2010a.

OSTROM, E. Polycentric systems for coping with collective action and global environmental change. Global Environmental Change, v. 20, n. 4, p. 550-557, 2010b.

OSTROM, E.; AHN, T. K. The meaning of social capital and its link to collective action. Workshop in Political Theory and Policy Analysi. Anais...Indiana University, 2006

OSTROM, E.; GARDNER, R.; WALKER, J. Rules, Games, and Common-Pool Resources. Ann Arbor: University of Michigan Press, 1994.

OSTROM, E.; WALKER, J.; GARDNER, R. Covenants with and without a sword: self-governance is possible. American Political Science Review, v. 86, n. 2, p. 404-417, 1992.

ÖZEROL, G. Institutions of farmer participation and environmental sustainability: A multi-level analysis from irrigation management in Harran Plain, Turkey. International Journal of the Commons, v. 7, n. 1, p. 73-91, 2013.

POTEETE, A. R.; OSTROM, E.; JANSSEN, M. A. Trabalho em parceria: ação coletiva, bens comuns e múltiplos métodos. Trad. Rogé ed. São Paulo: Editora Senac, 2011.

PULJAK, L.; VARI, S. G. Significance of research networking for enhancing collaboration and research productivity. Croatian Medical Journal, v. 55, n. 3, p. 181-183, 2014.

RUT'TAN, L. M. Sociocultural Heterogeneity and the Commons. Current Anthropology, v. 47, n. 5, p. 843-853, 2006.

SCOTT, A. D. The fishery: the objectives of sole ownership. Journal of Political Economy, v. 63, n. 2, p. 116-124, 1955.

SIMIYU, S. et al. Determinants of quality of shared sanitation facilities in informal settlements: Case study of Kisumu, Kenya. BMC Public Health, v. 17, n. 1, 2017.

SINN, H.-W. Common Property Resources, Storage Facilities and Ownership Structures: A Cournot Model of the Oil Market. Economica, v. 51, n. 203, p. 235-252, 1984.

SMITH, R. J. Resolving the Tragedy of the Commons by Creating Private Property Rights in Wildlife. Cato Journal, v. 1, n. 2, p. 439-468, 1981.

SOETANTO, R.; MULLINS, A.; ACHOUR, N. The perceptions of social responsibility for community resilience to flooding: the impact of past experience, age, gender and ethnicity. Natural Hazards, v. 86, n. 3, p. 1105-1126, 2017.

TABERNERO, C. et al. A multilevel perspective to explain recycling behaviour in communities. Journal of Environmental Management, v. 159, p. 192-201, 2015.

TRAVERS, H. et al. Incentives for cooperation: The effects of institutional controls on common pool resource extraction in Cambodia. Ecological Economics, v. 71, n. 1, p. 151-161, 2011.

VAN LAERHOVEN, F.; ANDERSSON, K. P. Community Forest Governance The virtue of conflict : an institutional approach to the study of conflict in community forest governance. International Forestry Review, v. 15, n. 1, p. 122-135, 2013.

VARUGHESE, G.; OSTROM, E. The contested role of heterogeneity in collective action: Some evidence from community forestry in Nepal. World Development, v. 29, n. 5, p. 747-765, 2001. 
VEDELD, T. Village politics: Heterogeneity, leadership and collective action. Journal of Development Studies, v. 36, n. 5, p. 105-134, 2000.

VOGEL, J. A.; LIND, H.; LUNDQVIST, P. Who is Governing the Commons: Studying Swedish Housing Cooperatives. Housing, Theory and Society, v. 33, n. 4, p. 424-444, 2016.

WASSERMAN, S.; FAUST, K. Social Network Analysis: Methods and Applications. Cambridge: Cambridge University Press, 1994.

WEISS, D.; SCZESNY, S.; FREUND, A. M. Wanting to get more or protecting one's assets: Agedifferential effects of gain versus loss perceptions on the willingness to engage in collective action. Journals of Gerontology: Psychological Sciences and Social Sciences, v. 71, n. 2, p. 254-264, 2016.

WENNINGKAMP, K. R.; SCHMIDT, C. M. Teorias da Ação Coletiva no Campo do Agronegócio: Uma Análise a Partir de Teses e Dissertações (1998-2012). Desenvolvimento em questão, v. 14, n. 35, p. 307-343, 2016.

WHITTEMORE, R.; KNAFL, K. The integrative review : Updated methodology. Journal of Advanced Nursing, v. 52, n. 5, p. 546-553, 2005.

WILSON, D. S.; OSTROM, E.; COX, M. E. Generalizing the core design principles for the efficacy of groups. Journal of Economic Behavior and Organization, v. 90, p. S21-S32, 2013. 